\title{
24. LITHOSTRATIGRAPHY AND CLAY MINERALOGY OF THE WESTERN MARGIN OF THE ROCKALL PLATEAU AND THE HATTON SEDIMENT DRIFT ${ }^{1}$
}

\author{
Herman B. Zimmerman, Union College ${ }^{2}$
}

\begin{abstract}
Learning more about the history of oceanic sedimentation and its relationship to the development of abyssal circulation in the northeastern Atlantic was a major objective of Leg 81 drilling. Accordingly, sites were situated on an EastWest traverse across the southwestern margin of Rockall Plateau and the Hatton Drift. All sites had a similar stratigraphic sequence of late Paleocene-early Eocene volcanogenic/shallow-water sediments lying below a major late Eocene-Miocene unconformity. Overlying this hiatus was a sediment-drift sequence of Mio-Pliocene pelagic ooze capped by a Plio-Pleistocene rhythmic sequence of ooze and marl deposited during glacial conditions. The clay-mineral components of these sediments reflect the developing exchange of water between the northeastern Atlantic and the Norwegian Sea as the Greenland-Scotland Ridge subsided during the Cenozoic. Evidence presented here suggests an early Eocene initiation of the Northeast Atlantic Passage. Major flow through this passage in the late Eocene/Oligocene stimulated changes in abyssal circulation throughout the North Atlantic, the regional mid-Tertiary unconformity being the most dramatic result.
\end{abstract}

\section{INTRODUCTION}

An important objective of Leg 81 of the Deep Sea Drilling Project (DSDP) was to examine the sedimentary record of the northeastern Atlantic in the vicinity of the western margin of Rockall Plateau. This study focuses on the paleoceanographic history of this region as inferred from the evolution of clay mineral assemblages.

Previous studies have shown that the history of oceanic circulation and sedimentation in the northern Atlantic is closely tied to the tectonic evolution of the Greenland-Scotland Ridge, one of the world's major aseismic ridges (Jones et al., 1970; Ruddiman, 1972; Roberts, 1975; Berggren and Hollister, 1974; Roberts and Montadert, 1979; Miller and Tucholke, in press). The ridge acts as a barrier to longitudinal flow of deep water while allowing interchange across relatively shallow sills (Worthington, 1970; Ellett and Martin, 1973; Ellett and Roberts, 1973). Sediment source and depositional pattern around the flanks of the Rockall Plateau have been greatly influenced by the abyssal circulation associated with the overflow from the Norwegian Sea. Under the present current regime (Fig. 1), the western base of the Rockall Plateau underlies a bottom-water current flowing to the northeast (Ruddiman, 1972; McCave et al., 1980). According to McCave et al. (1980), this flow consists of Iceland-Scotland Overflow Water (ISOW) which has rounded the southern end of the plateau after passing over Feni Drift in the Rockall Trough. The deeper drill sites (Sites 552, 553, and 554) of Leg 81 lie beneath this northeastward flow. To the west, North Atlantic Deep Water (NADW) flows southward along the flanks of the Reykjanes Ridge and fills the deeper regions of the Iceland Basin.

\footnotetext{
${ }^{1}$ Roberts, D. G., Schnitker, D., et al., Init. Repts. DSDP, 81: Washington (U.S. Govt. Printing Office).

2 Address: Department of Civil Engineering, Union College, Schenectady, NY 12308.
}

The sediment section in this area, as inferred from seismic profiles (site chapters, this volume) and previous drilling (Montadert and Roberts, 1979), consists of a wellbedded volcaniclastic sequence below a prominent seismic reflector that represents a late Eocene-Miocene unconformity. Overlying this hiatus is a transparent "drift" sequence of Mio-Pliocene pelagic ooze capped by a Plio-Pleistocene rhythmic sequence of ooze and marl. The onset of Neogene sedimentation throughout the North Atlantic is marked by seismic reflector 1a (this volume, "R4" of Roberts, 1975; "R" of Jones et al., 1970; and Ruddiman, 1972), and the pelagic sediments overlying this horizon have been fashioned into a series of prominent sediment drifts. Hatton Drift mantles the base of the western margin of Rockall Plateau. Sites 552 and 553 (Fig. 1) are located near the crest of the drift, while Site 554 is situated on its deeper western flank. Site 555 is shallower and situated in a saddle between Hatton and Edoras banks, which form the southwestern corner of Rockall Plateau.

Cores recovered by drilling on Leg 81 provide an excellent stratigraphic framework with an adequately high stratigraphic resolution to allow studies on the evolution of clay-mineral assemblages. In the North Atlantic, previous clay-mineral studies of the Tertiary stratigraphic sequence include: Latouche (1979), Latouche and Maillet (1979), and Debrabant et al. (1979). Latouche (1979) summarizes the region's clay-mineral stratigraphy as consisting of three successive sedimentary episodes: an early Cenozoic environment of highly variable sedimentation under depositional conditions peculiar to individual basins, a late Eocene transitional phase, and the modern phase with uniform pelagic sedimentation over the entire northeastern Atlantic region.

\section{METHODS}

Samples were taken from the four sites so that good representation was obtained of all sediment facies and characteristic horizons. Over 200 samples, at an average downcore interval of about $10 \mathrm{~m}$, were analyzed by standard X-ray diffraction (XRD) procedures. 


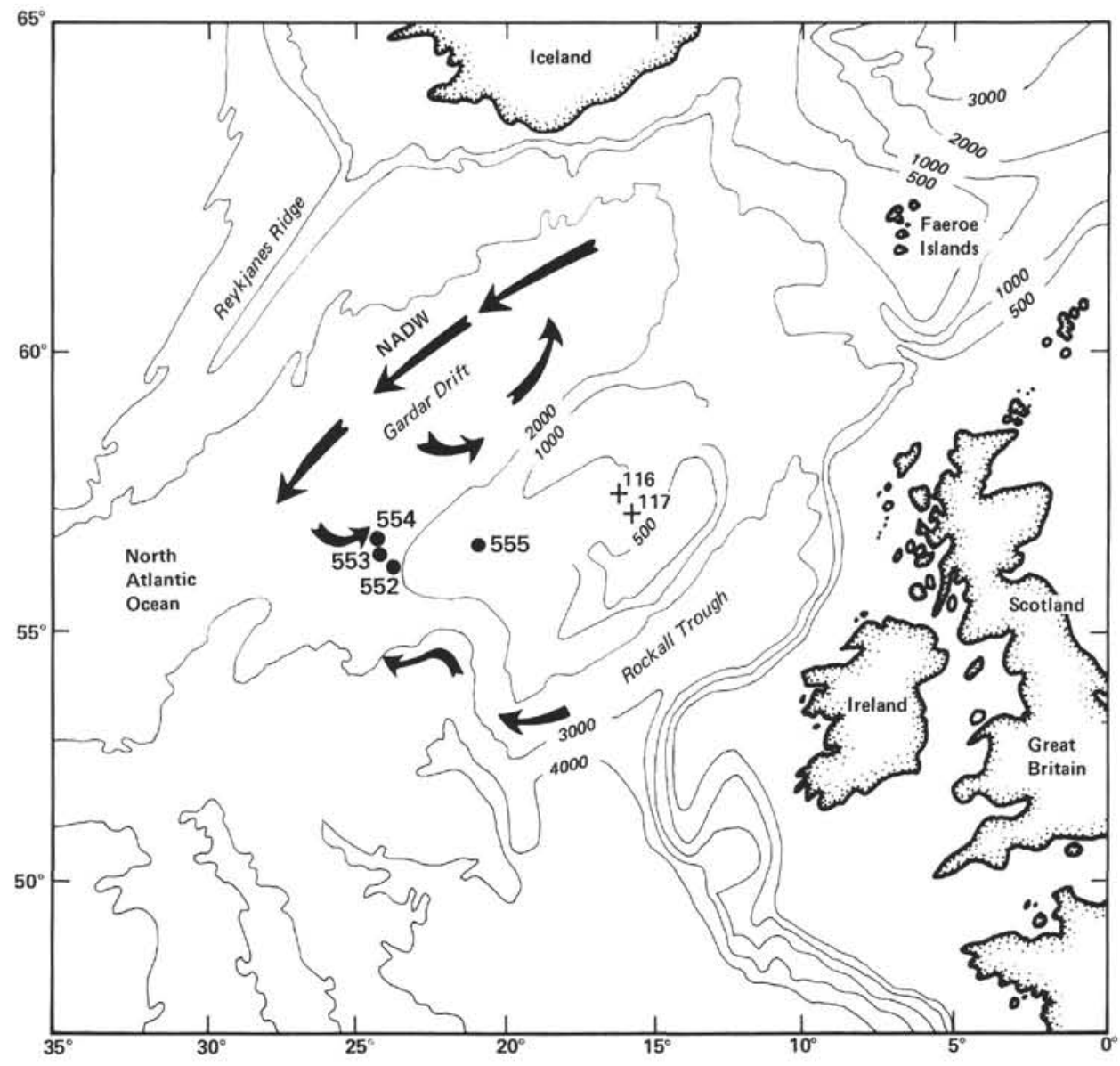

Figure 1. Regional setting of the northeastern Atlantic, showing locations of drill sites and the modern pattern of bottom current flow.

Detailed descriptions of sample preparation for XRD analysis are given in Biscaye (1965) and Jackson (1969). Calcium carbonate was removed by overnight treatment with $0.6 \mathrm{~N}$ acetic acid solution, followed by successive decantation until floculation ceased (usually three repetitions), then settling in accordance with calculated times to allow separation of the $2-37 \mu \mathrm{m}$ (silt) and $<2 \mu \mathrm{m}$ (clay) size fractions. The two separate suspensions were then concentrated by decantation to remove excess water and the sediment pastes smeared on glass slides (Gibbs, 1968). Each slide was analyzed by XRD both before and after ethylene-glycol solvation $\left(1 \mathrm{hr}\right.$. at $\left.60^{\circ} \mathrm{C}\right)$. Both slide sets were run through a scan of $3-35^{\circ} 2 \theta$ at a scan speed of $2^{\circ} 2 \theta / \mathrm{min}$, with a subsequent slow scan speed in the $24-26^{\circ} 2 \theta$ range. Analysis was performed with a General Electric XRD-7 diffractometer with nickel-filtered $\mathrm{CuK}_{\alpha}$ radiation.

Major mineral phases on the clay slide were identified by their basal reflections. The area under the $7.1 \AA$ peak was used as an abundance indicator of chlorite and kaolinite, with the slow-scan method of Biscaye (1964) applied as a means of identifying and separating these two minerals. Illite (or mica) was recognized by a well-defined peak at $10 \AA$ that was unaffected by ethylene-glycol solvation. Irregular mixed-layer (illite-smectite) clay was estimated by calculating the area above background between the $10 \AA$ illite and $14 \AA$ chlorite peaks. A broad $17 \AA$ peak after solvation was assigned to smectite (montmorillonite) and the $17 \AA$ peak area was employed as an indicator of the relative abundance of "smectite." Reynolds and Hower (1970) have demonstrated that a $17 \AA$ peak probably represents pure montmorillonite or a mixed-layer mica-montmorillonite, with a decreasing peak intensity and a broader peak representing an increasing abundance of mica layers (see also Hayes, 1973 and Eslinger and Savin, 1976).

Semiquantitative estimates of the relative amounts of crystalline clay components were determined by concentration factors described by Biscaye (1965) whereby proportions of smectite, mixed-layer (illitesmectite), kaolinite, illite, and chlorite are normalized to $100 \%$.
In complex sediment mixtures, areas beneath XRD peaks provide an indication of mineral abundance, orientation, absorption, crystal perfection, and compositional variations. Inspection of the diffractograms for this study revealed the potential of the total clay reflectivity as a potent measure of clay variation. We have chosen the term "total clay index" (TCI) for this because of the covariance and contribution of all the clay-mineral peak-areas to this measure (previously termed "crystallinity index" in Zimmerman, 1982a). The most convenient way to quantify this measure was to sum the areas (in square millimeters) above background of the 17-, 10-, 11- to $12-$, and $7.1 \AA$ peaks (solvated, under constant machine conditions) after multiplying by the factors of Biscaye (1965). Two diffractogram traces, therefore, may indicate approximately the same relative abundance of individual clay mineral species, but the TCI may differ significantly. The TCI probably reflects both the abundance and crystal perfection of all clay minerals present as well as the presence of amorphous components and organomineral components. In the North Atlantic (Zimmerman, 1982b), the TCI is valuable for identifying mineral provinces that are dependent on source area, current transportation, basin physiography, and primarily the rate of fine-fraction deposition.

Another measure that is effective in interpreting sedimentary history associated with deep-ocean deposition is the ratio: TCI/quartz (calculated from dimensionless values of TCI and quartz intensity). The intensity of the quartz peak ( $4.26 \AA)$ describes the silt-sized $(2-37 \mu \mathrm{m})$ continental contribution. The ratio, therefore, serves as a measure of the relative contribution of clay-sized and silt-sized sedimentary components. In Figures 3-6 the presence of zeolites, amphibole, cristobalite, and other minerals are also noted for the silt-sized component.

\section{RESULTS}

In ascending order, the stratigraphic section is divisible into the following lithofacies common to all sites (Fig. 2): basalt flows with interbedded sediment, volcaniclas- 


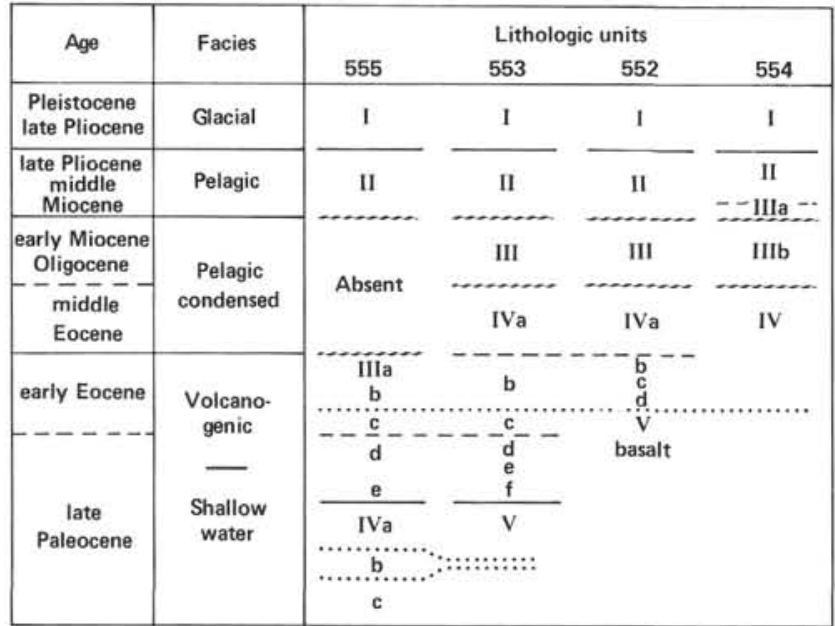

Figure 2. Lithostratigraphic correlation scheme for Leg 81 sites. Wavy lines are unconformable contacts. Dashed and dotted lines for correlation. tic shallow-water sediments, a pelagic-condensed sequence that is correlative with seismic reflector 1a, pelagic-drift sediments, and a cyclic glacial-interglacial sequence at the top of the section.

\section{Sites 552 and 553}

\section{General Lithology and Stratigraphy}

Sites 552 and 553 are located only $8 \mathrm{~km}$ apart near the crest of Hatton Drift and are therefore treated together. On-board sedimentologic comparisons established a similar sequence of lithologic units (Figs. 3 and 4). Unit I, the uppermost sediments at both sites, consists of cyclic pelagic ooze, marl, and mud of Plio-Pleistocene age and represents the sedimentologic response to Northern Hemisphere glaciation. The cyclic character is absent in Unit II, which consists of Miocene-late Pliocene foraminifer-nannofossil ooze and chalk; the sequence becomes increasingly glauconitic at the base (Subunit IIb).

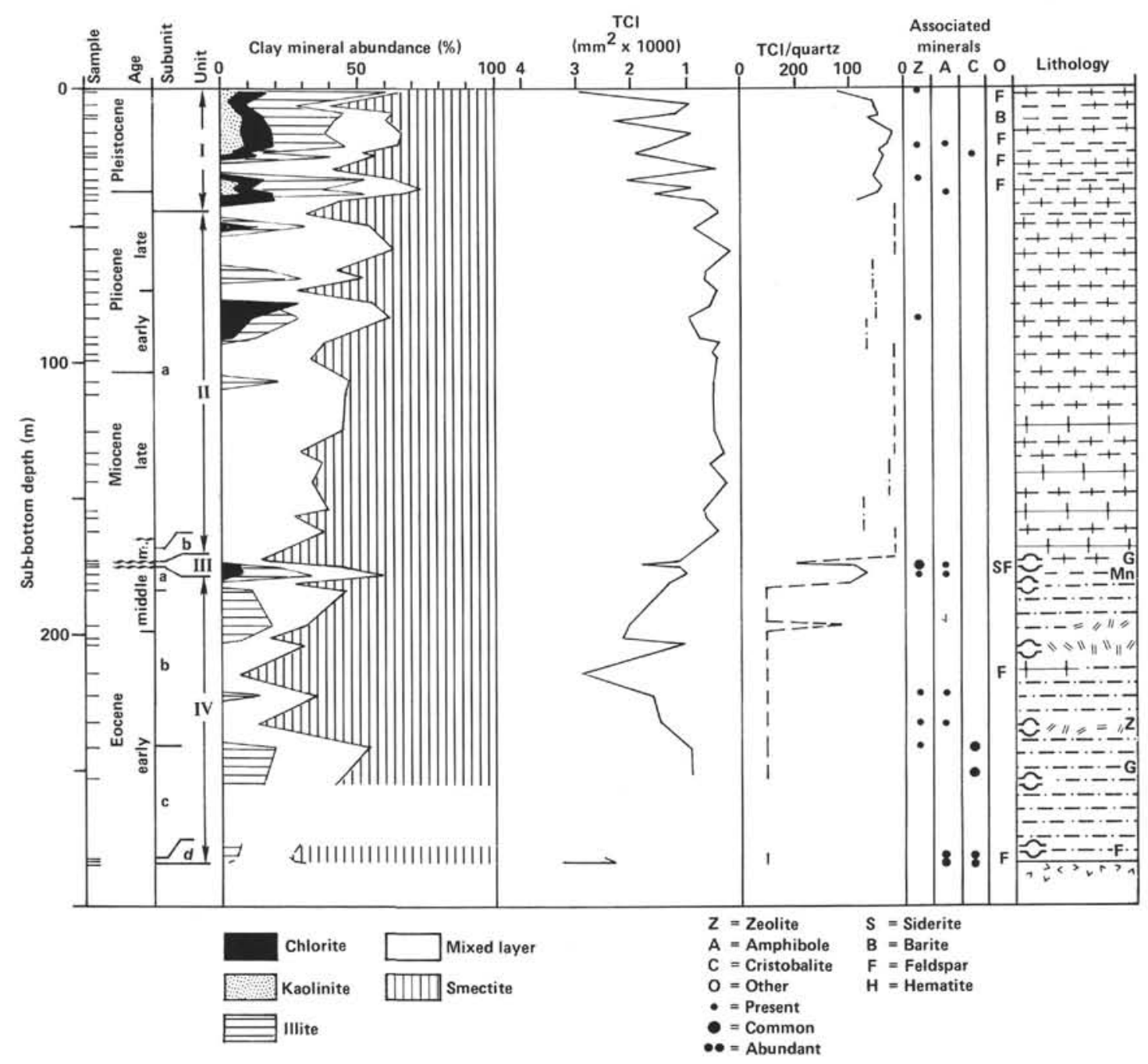

Figure 3. Summary of lithostratigraphic and mineralogical data for Site 552, Leg 81 DSDP. Where TCI/quartz ratio is a high value and noted by a dashed line, a high TCI value is indicated but with only trace amounts of quartz. In the absence of quartz and in conjunction with a low TCI value, a low TCI/quartz ratio has been arbitrarily plotted. 


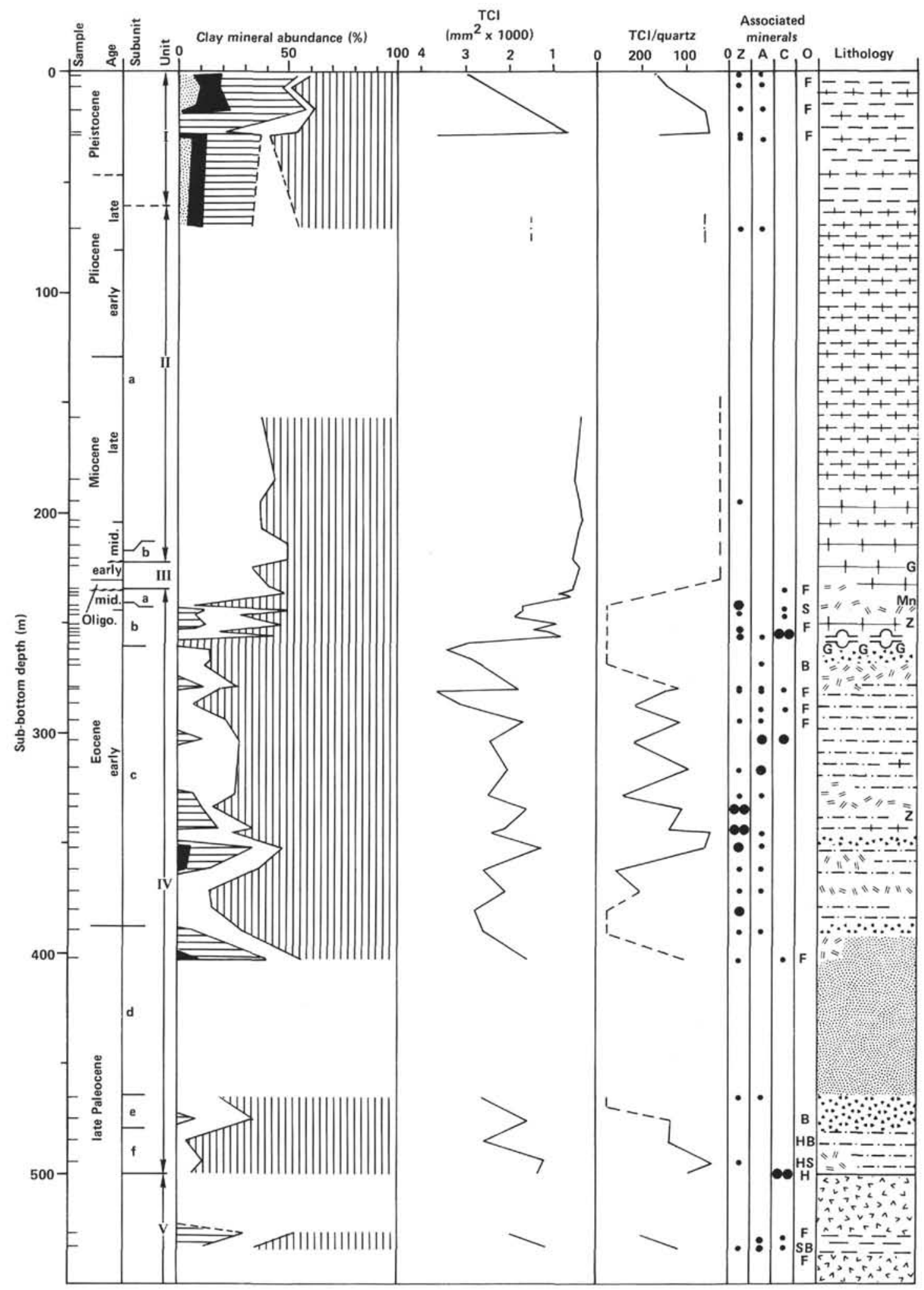

Figure 4. Summary of lithostratigraphic and mineralogical data for Site 553, Leg 81 DSDP. (See Figure 3 for legend.)

Unit III is a condensed stratigraphic sequence containing several hiatuses which span approximately $30 \mathrm{~m} . \mathrm{y}$. of geologic time between mid-Eocene and mid-Miocene. The sediments are variable in lithology and consist of chalk, ash, and manganese hardgrounds.
The lithology of Unit IV is dominated by volcanogenic and shallow-water terrigenous silts and clays. Subunit IVa is mid-Eocene and consists of biosiliceous nannofossil chalks; benthic foraminifers indicate depth of deposition was greater than $700 \mathrm{~m}$ (site chapters, Sites 
$552,553)$. Subunit IVb at Site 553 is correlative with the lowest sediment section at Site 552 (Subunits IVb, c, and d; Fig. 2). These early-mid-Eocene sediments are composed principally of tuffs interbedded with glauconitic mudstones and zeolitic and biosiliceous chalks. Macrofossils are common and benthic foraminifers indicate deposition at about 100- to 700-m depth at Site 553; sediments of equivalent age at Site 552 were deposited at mid-shelf depths of 75-100 m (site chapters, Sites 552, 553).

Underlying sediments of Unit IV are present only at Site 553. Chalks are absent, but detrital quartz grains are common. A change in heavy-mineral content, from an augite-iddingsite suite above to epidote-hornblende below takes place near the base of Subunit IVb (Morton, this volume). Subunit IVc consists predominantly of volcanic tuff and interbedded mudstones. A rich macrofauna and carbonaceous material are also common in these mudstones; environments indicated as sites of deposition range from lagoonal or estuarine conditions to inner shelf.

The underlying late Paleocene-early Eocene sediments of Subunit IVd are not well represented owing to poor recovery. The few fragments that are available, however, consist of micaceous arkosic sandstones. Subjacent to this, Subunit IVe consists almost wholly of volcanic lapilli, and Subunit IVf is a sandy tuffaceous mudstone representing a basal transgressive deposit overlying basalt. Between the basalt flows of Subunit Va, a small amount of similar sedimentary material was also recovered.

\section{Clay Minerals}

The clay-mineral assemblages at Sites 552 and 553 are dominated by smectite with relatively large amounts of illite in both the uppermost and lowest portions of the section (Figs. 3 and 4). Chlorite appears to vary in sympathy with the illite content. The clay-mineral variability taken along with the TCI allows the section to be divided into facies that approximately correspond to the lithologic units noted above.

The TCI of Subunits IVc, e, and f (Site 553) is relatively high as a result of the abundance of the clay component. A high TCI/quartz ratio indicates the general predominance of clay over quartz silt, although many samples in Subunit IVc have distinctly low ratios marking zones where quartz silt is more abundant. The sediment interbedded with the basalt flows (Subunit Va) is similar, with a significant illite component and a low TCI/ quartz ratio. These characteristics suggest that, in addition to the primary basaltic terrane, a continental source has also contributed to this lithofacies. This conclusion was also reached by Harrison et al. (1979), who note that the record of volcanism associated with the opening of the North Atlantic is obscured by argillization processes and by dilution with terrigenous detritus. The heavy mineral suite of metamorphic hornblende and epidote (Morton, this volume) suggests a metamorphic basement including amphibolites. In light of late Paleocene paleogeographic reconstructions (Fig. 7). the terrigenous source at this time could have been Rockall Plateau and/or the land mass of southeastern Green- land. The dominant well-crystallized smectite component, however, points to a subaerial basaltic terrane as the primary source for these late Paleocene-early Eocene sediments. Courtois and Chamley (1978), on the basis of rare-earth studies, reached a similar conclusion for Eocene sediments of the Rockall Plateau.

Overlying this section are early to mid-Eocene sediments of Subunit IVb (Site 553) and the equivalent section at Site 552, Subunits IVb, c, and d. In clay composition (Figs. 3 and 4) these sediments are similar to those below; smectite predominates with a variable illite content. The chief difference, however, is in the TCI/quartz ratio, which is very high, indicating the decrease of detrital quartz silt. The heavy mineral suite also changes near the base of this sequence and is reflected in the absence of fine-grained amphibole above the subunit's base. Basal sediments at Site 552 (Subunit IVb), however, contain a significant amount of amphibole, suggesting that they may correlate better with Subunit IVc of Site 553. Reflecting the increasingly oceanic nature of the region, these early to mid-Eocene sediments contain only a minor terrestrial clay component and, taken together with the first occurrence of nannofossil chalks and biosiliceous marls (site chapters, Sites 552, 553), are characteristic of outer-shelf to upper-slope environments.

Subunit IVa (Sites 552 and 553) is mid-Eocene, consists of only a few meters of biosiliceous nannofossil chalks, and appears to represent a transitional sequence between the volcanogenic sediments below and the pelagic chalks above. In clay-mineral composition, the subunit consists of smectite and mixed-layer minerals. Illite and chlorite are present at Site 552. The TCI is lower than the preceding sediments, suggesting a lower rate of clay deposition or dilution by the carbonate component. Similar to the underlying sediments, the high TCI/ quartz ratio reflects the virtual absence of quartz silt.

Unit III (Sites 552 and 553) consists of a mid-Eocene to early Miocene condensed sequence representing a prolonged period of pelagic deposition and intermittent erosion. This is overlain by Unit II, which consists of MioPliocene pelagic chalk and ooze. The fine fraction of both units is quite similar. Within Unit III and the Miocene portion of Unit II, the clay composition consists entirely of smectite and mixed-layer clays with a low TCI. The base of Unit III is marked by an abrupt decrease in the TCI/quartz ratio. The low TCI and the low $\mathrm{TCI} /$ quartz ratio in Units II and III indicate an almost complete absence of clay and small amounts of quartz silt, characteristics that reflect a limited terrigenous influence on these sediments. The Pliocene portion of Unit II, however, is distinguished by the occasional presence of illite, chlorite, and some kaolinite and probably reflects the initiation of increasingly active erosional processes in the Northern Hemisphere.

The glacial influence is best recorded by the late Pliocene and Pleistocene sediments recovered at hydraulicpiston cored Hole 552A, where a complete and undisturbed glacial/interglacial sequence is present (Zimmerman et al., this volume). Although similar lithologies and cyclicity mark the glacial deposits recovered at Sites 553,554 , and 555 , the sediments at these sites are mod- 
erately to highly disturbed by the rotary-drilling process and stratigraphic continuity has not been maintained. From the abrupt initiation of cyclic sedimentation 2.4 m.y. ago at the base of Unit I (Hole 552A), the sediments alternate between pelagic ooze of the interglacial stages and muds of the glacial stages. Carbonate content in this region is primarily controlled by biologic productivity in the overlying waters and dilution by ice rafting or other sediment influx. At the most extreme of the glacial stages, ice cover may have greatly reduced or even eliminated pelagic carbonate input to these sediments.

The clay-mineral content of Unit I also reflects the cyclic nature of those sediments. The cycles presented in Figures 3 and 4 are only representative of the approximately 30 cycles that have been identified. Clays of the interglacial stages are predominantly smectite and mixedlayer minerals; TCI and TCI/quartz ratio are low, indicating the absence of terrestrial input. These sediments are similar, therefore, to the pelagic lithofacies of Miocene Unit II. In the interglacial and Miocene North Atlantic, the volcanic terrane of the Iceland-Faeroe region provides the most likely source for the fine-grained component of this lithofacies, albeit in small amounts.

The clay suite of the glacial stages reflects a terrigenous origin, containing a significant abundance of illite (approximately $30 \%$ ), chlorite, and kaolinite. The TCI of these sediments indicates a high rate of clay-mineral deposition. Examination of the X-ray diffractograms reveals a significant quartz-silt component; the low TCI/ quartz ratio, therefore, suggests a high rate of quartzsilt deposition and emphasizes the importance in this area of the ice-rafted component under glacial conditions.

\section{Site 554}

At the base of the Hatton Drift, Site 554 lies above the "outer high," the first oceanic crust in this area (site chapter, Site 554). The stratigraphic lithology (Fig. 2) and fine-fraction mineralogy (Fig. 5) are similar to the sequence described above for Sites 552 and 553. Unit I represents Pleistocene cyclic sediments; the early glacial sequence is absent. The pelagic sequence (Miocene-early Pliocene) is represented by Unit II and is marked by a glauconitic chalk at the base (Subunit IIIa). Beneath this, the condensed sequence (Subunit IIIb) consists of pelagic chalks and marls overlying a manganese hardground at the base. As at the other sites, this late Eocene/Oligocene period of erosion and interrupted deposition denotes a major change in North Atlantic paleoceanography. These sediments in turn overlie an early Eocene volcanogenic sequence of zeolitic tuffs and marlstones (Unit IV) and volcanogenic conglomerates and sandstones interbedded with basalt flows (Unit V). This sequence is not well represented at this site, but is similar in character to sediments of the same stratigraphic position at the other sites. The clay-mineral assemblage (Fig. 5) is also similar to that of the other sites. The early Eocene terrigenous input is absent in the volcanogenic sediments, suggesting that only the upper portion of the sequence is present.

\section{Site $\mathbf{5 5 5}$}

At the eastern terminus of the Leg 81 transect, Site 555 is situated in $1659 \mathrm{~m}$ of water in the saddle between Hatton and Edoras banks. This site is located in the zone of rapid crustal thinning and, although most landward of the Leg 81 sites, can be considered transitional in position between the thick crust of the Rockall Plateau microcontinent to the east and the thinner oceanic crust on the west (site chapter, Site 555).

Although generally exhibiting greater terrestrial affinities, the thick sedimentary sequence follows a pattern quite similar to the deeper sites (Fig. 6). Of the deeper sites, Site 553, with the most complete stratigraphic section, will be used for comparison.

The oldest sediments of Site 555 are late Paleocene (Subunit IVb) and consist of tuffs interbedded with micaceous, quartzose, and feldspathic sands and silts. Although smectite dominates the clay-mineral assemblage, significant amounts of illite and chlorite suggest an important terrigenous contribution. The TCI is highly variable and this is reflected in the TCI/quartz ratio; where

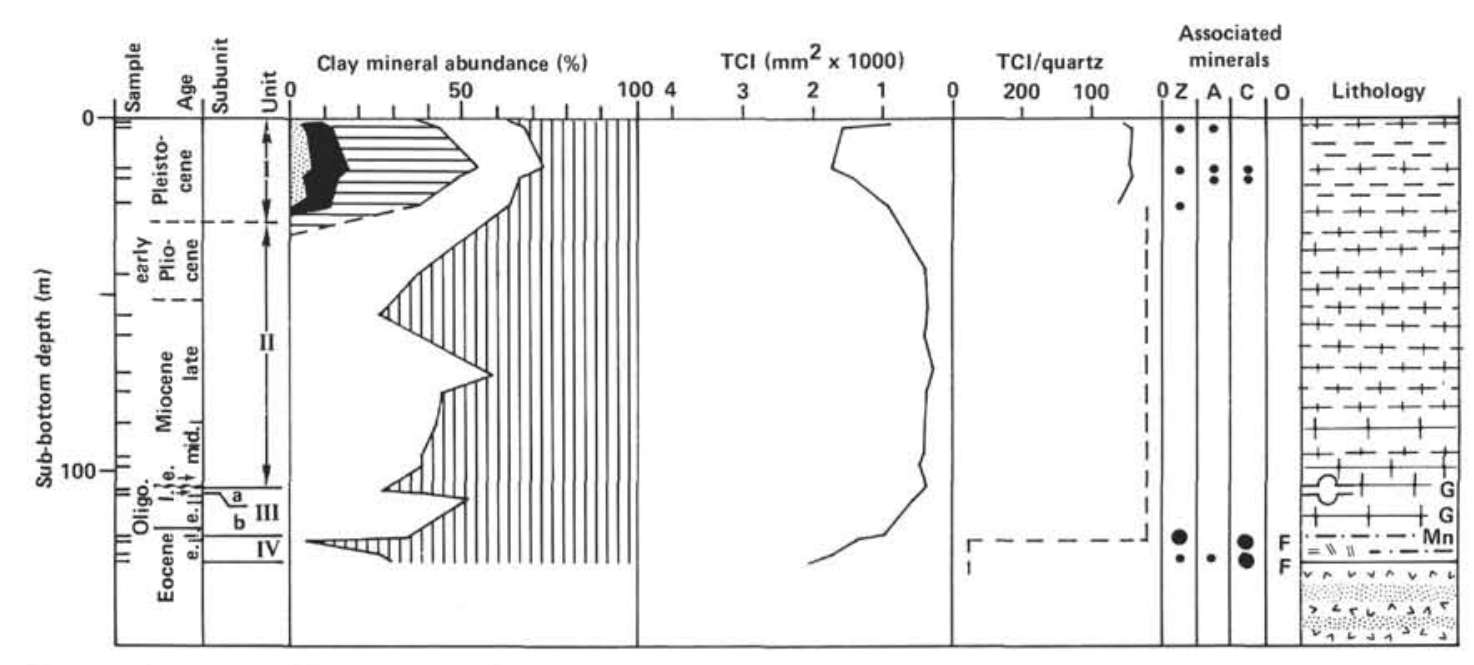

Figure 5. Summary of lithostratigraphic and mineralogical data for Site 554, Leg 81 DSDP. (See Figure 3 for legend.) 
low, the ratio indicates significant amounts of quartz silt. The lithology of these sediments and their stratigraphic position (Fig. 2) indicate that they are correlative to the sediments interbedded with basalt flows of Site 553 (Unit V).

Above the basalt flows and pillows of Subunit IVa, lithologically diverse sediments are grouped together as Unit III because of their fundamentally volcanogenic characteristics. Subunits IIIc and d are late Paleoceneearly Eocene and equivalent to Subunits IVc and d at Site 553 (the base of Subunit IIIe at Site 555 may be equivalent to Site 553 - Subunit IVf, but the correlation is difficult to make on the data available). The claymineral assemblage continues to suggest an important continental influence in these sediments, but smectite of basaltic origin remains the dominant clay. Wide variation in the TCI and TCI/quartz ratio in Subunit IIIc and the lower portion of Subunit IIId is indicative of the laminated silts and clay comprising these sediments and of the shallow-water environment in which they were deposited. Variability in lithology decreases somewhat within Subunit IIId, suggesting more uniform conditions of deposition under moderating current activity. This is also suggested by the increased preservation of organic material. Carbonaceous mudstone and feldspathic sandstone continue to occur into the lower Eocene sequence of Subunit IIIc. In these sediments, volcanic and lapilli tuffs are prominent, thus correlating with the volcaniclastic sediments of Subunit IVc of Site 553. The claymineral assemblage and other lithologic indicators also correspond closely to Site 553 (Figs. 4 and 6).

The base of Subunit IIIb and the equivalent Subunit IVb at Site 553 is marked by the appearance of abundant glauconite. This is seen clearly in the clay-mineral abundance as a distinct smectite/mixed-layer assemblage which appears to be the glauconitic smectite variety of Odin and Matter (1981). The epidote-amphibole heavy mineral association disappears close to the Subunit $\mathrm{IIIb} / \mathrm{c}$ boundary (Morton, this volume) marking the cessation of sediment supply from the southeastern Greenland area. The abundance of glauconite and the similarity of the clay-mineral assemblage above this horizon indicate that these sediments are equivalent to the lower part of Subunit IVb at Site 553 and represent the same transgressive event.

The remaining Eocene sediments of Unit III consist of a number of lithologies ranging from vitric tuff and spiculite to zeolitic chalks and macrofossil limestone (Subunit IIIa). Although the lithologies are extremely variable, the clay-mineral assemblage is remarkably constant with smectite and mixed-layer clays dominating, and an illite content of $20-40 \%$. These characteristics establish an equivalency between these sediments and the upper sediments of Subunit IVb of Site 553 (Figs. 4 and 6).

One of the few lithologic factors that does not completely correspond is the TCI/quartz ratio, which at Site 555 (Subunit IIIa) continues to indicate the presence of small amounts of quartz silt whereas in the equivalent sediments of the upper part of Site 553 (Subunit IVb) quartz silt is absent. This may reflect the growing differ- ential in paleodepth between the sites and the landward position of Site 555. The supply of terrigenous silt to the deeper areas at the base of the Hatton Escarpment appears to have been eliminated at this point.

At Site 555 the condensed pelagic sequence is absent; an early Eocene-early Miocene unconformity marks the Unit III/II boundary. Units I and II (Site 555) are identical to the pelagic and glacial sequences at the other sites. Very little clay or detrital material is found in the calcareous Miocene sediments; and at this site, Units I and II are separated by a hiatus. The Pleistocene sediments of Unit I exhibit the cyclical glacial/interglacial characteristics common to these sediments throughout the North Atlantic.

\section{DISCUSSION}

All sites on the western margin of the Rockall Plateau show sedimentary sequences deposited in response to tectonic and paleoceanographic events in the eastern North Atlantic Ocean.

Late Paleocene to early Eocene time is characterized by a volcanogenic-shallow-water facies interbedded with basalt flows. These lithofacies consist of clays, quartzose silts, and volcanoclastic debris. Smectite is the most abundant clay mineral in this facies and, in association with basalts and volcanoclastic sediments, is recognized as a weathering product of volcanic terranes. Illite, kaolinite and chlorite, and quartz and feldspathic silts are present in variable quantities and represent the terrigenous component contributed from the surrounding land mass of Greenland-Rockall Plateau (Fig. 7A). These two components of the lithofacies, volcanoclastic and detrital continental, characterize the sediments throughout the late Paleocene and much of the early Eocene. Although one or the other dominates in alternating fashion (Figs. $3,4,5,6$ ), both components are always present. Associated with the preservation of carbonaceous plant debris, macrofossils, flaser bedding and occasional indications of scour, the depositional environment for these sediments appears to be shallow tidal flats or a tidal basin characterized by episodes of shoaling and deepening. The high rate of sediment accumulation (site chapters) further suggests deposition in a rapidly subsiding basin with an abundant sediment supply balancing subsidence. Overall, however, we view these sediments as a transgressive sequence reflecting the decreasing frequency of volcanic eruptions and the region's progressive subsidence.

After a final pulse of volcanoclastic debris marking the last major pyroclastic event in the immediate area, the fine fraction becomes more marine in character in the early Eocene (Zone NP10 - the base of Subunit IIIb, Site 555; Subunit IVb, Site 553). These sediments are characterized by their concentration of smectitic glauconite, the elimination of significant amounts of detrital quartz, and a change in the heavy-mineral association (Morton, this volume). Widening of the Iceland Basin and the accelerating subsidence of the Thulean Land Bridge has apparently cut the sediment influx from Greenland. We suspect that this horizon, therefore, rep- 


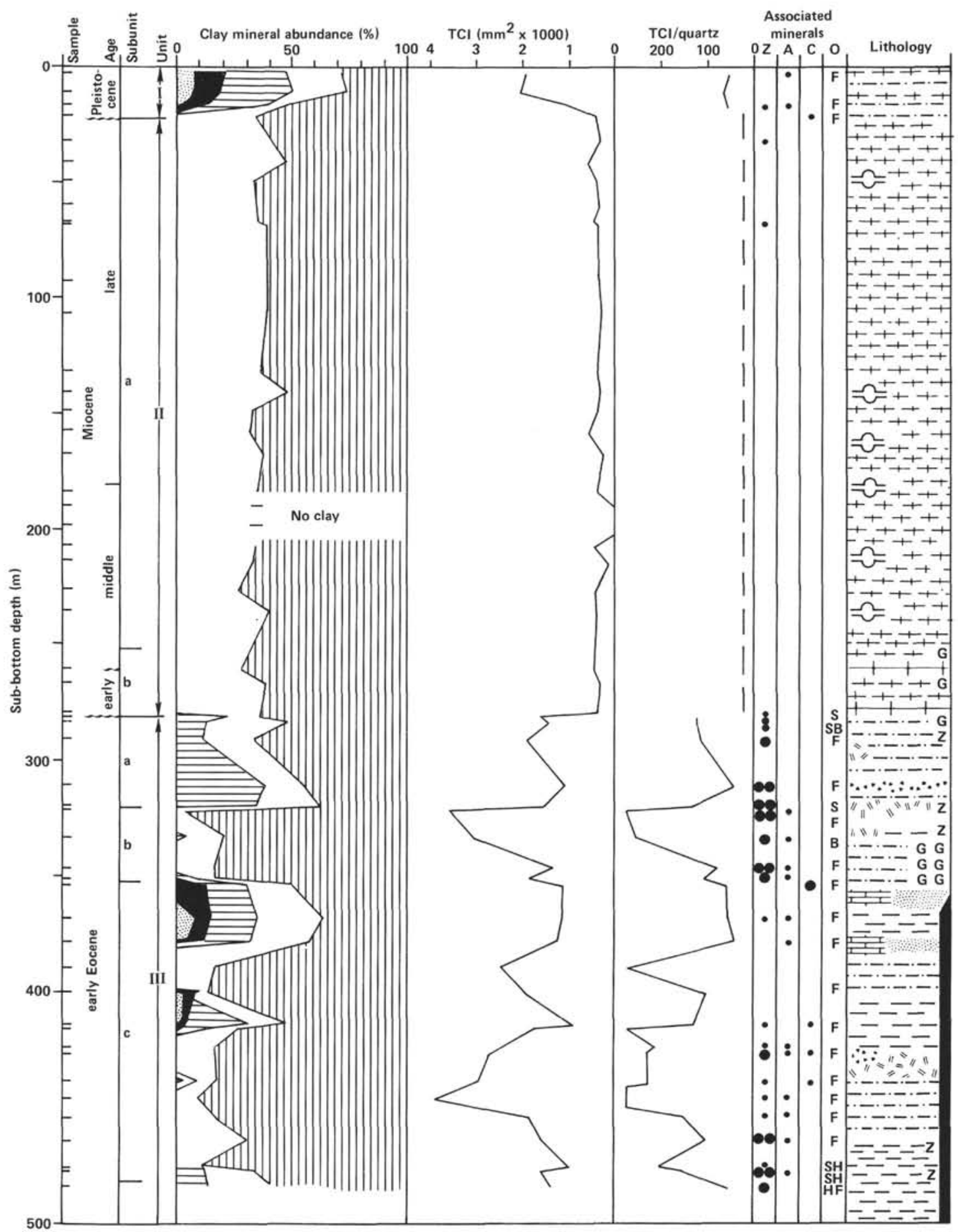

Figure 6. Summary of lithostratigraphic and mineralogical data for Site 555, Leg 81 DSDP. (See Figure 3 for legend.)

resents the initiation of the Northeast Atlantic Passage for surface-water flow between the Norwegian Sea and the northeastern Atlantic.

The initiation and subsequent development of the exchange of water between the Norwegian-Greenland Sea and the North Atlantic has been the source of considerable debate. Primarily on the basis of subsidence models, the onset of a surface-water connection across the Greenland-Scotland Ridge has been placed at, or subsequent to, the Eocene/Oligocene boundary by a number of au- thors (Vogt, 1972; Talwani and Udintsev, 1976; Thiede, 1980). On the basis of nannofossil gradients, Müller (1976) suggests that, except for a brief middle-late Oligocene influx of North Atlantic water, the Norwegian Sea remained separated from the North Atlantic from middle Eocene to late Miocene-Pliocene. Other lines of evidence, however, indicate an earlier breach in the Thulean Land Bridge: the distribution of planktonic organisms (Haq, 1981), the oxygen-isotopic record of a cooling in the North Atlantic at the early/middle Eocene 


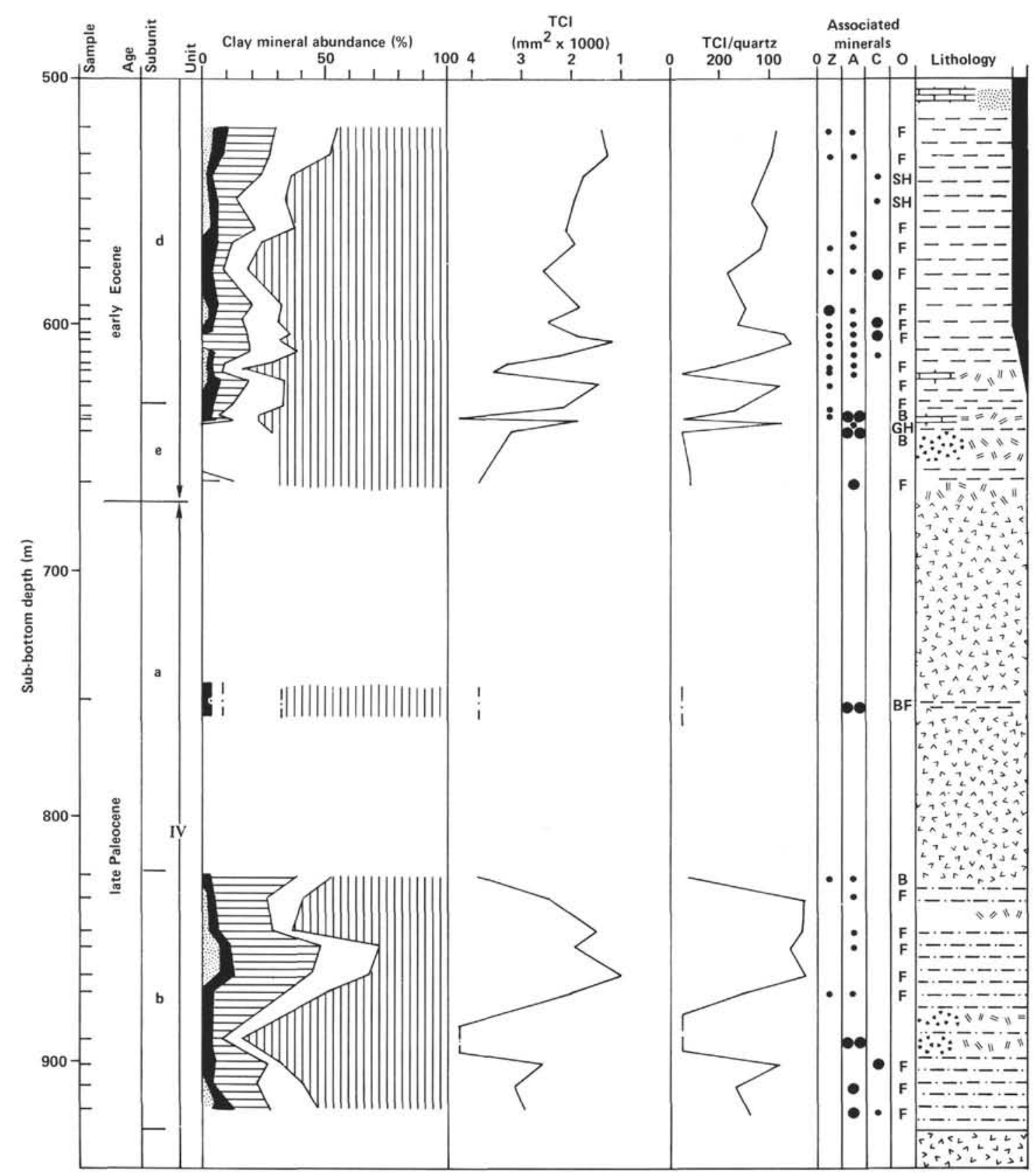

Figure 6. (Continued).

boundary (Vergnaud-Grazzini et al., 1978; Goldstein and Anderson, 1981), and the differentiation of terrestrial fauna between Eurasia and North America/Greenland (McKenna, 1975). In reviewing these arguments, Miller and Tucholke (in press) conclude that "surface-water connections between the northern Atlantic and the Norwegian-Greenland Sea probably existed more or less continuously from the early Eocene onward." The evidence presented here from the sediments of the southwestern flank of the Rockall Plateau is in agreement with that assessment. The change in sediment characteristics, occurring within nannoplankton Zone NP10 (Backman, this volume), is consistent with the opening of a seaway between Greenland and the Rockall Plateau at this time.
Deposition of the first pelagic chalks commences in the middle Eocene at the deeper sites (Sites 552, 553, 554), but soon after this, sedimentation over the entire region is interrupted. The condensed/pelagic facies at the deeper sites and the complete hiatus at Site 555 marks the late Eocene/Oligocene unconformity and constitutes compelling evidence for a major change in depositional conditions and regional circulation. Although the precise timing of the events associated with the separation of Greenland and Scotland is as yet uncertain, the sedimentary sequence described here suggests an earlymiddle Eocene initiation of significant amounts of overflow water of sufficient intensity to prevent deposition over wide areas of the North Atlantic. This flow was apparently not limited to the deeper flow paths in the nas- 

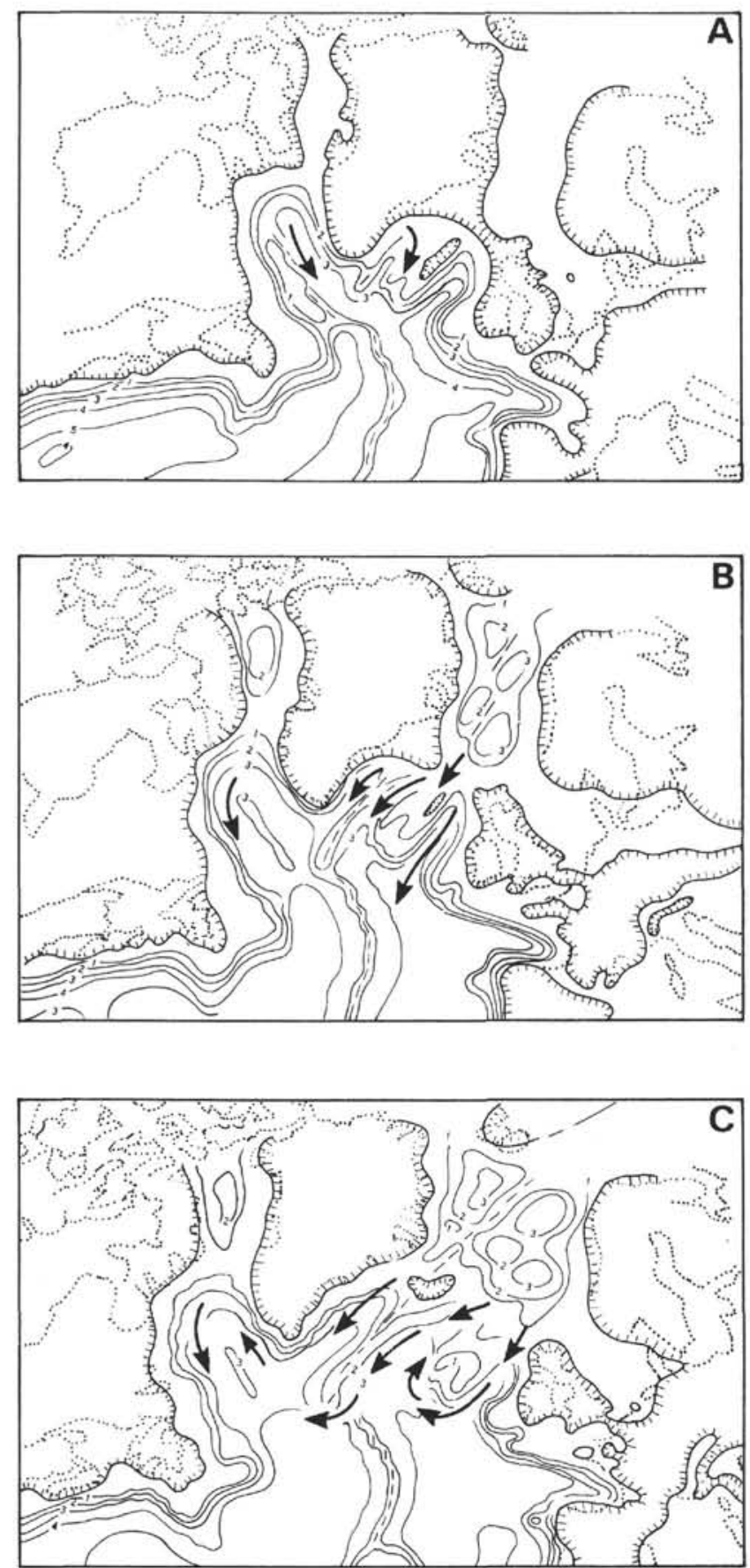

Figure 7. Model of paleoceanographic events associated with the subsidence of the Greenland-Scotland Ridge. Arrows indicate direction of bottom flow. Geographic reconstructions after McCoy and Zimmerman (in press). A. Latest Paleocene. Deposition of the shallow-water volcanogenic facies; the Thulean Land Bridge prevents exchange of water between the Norwegian Sea and the North Atlantic. B. Latest Eocene. Initiation of the Northeast Atlantic passage; formation of the late Eocene/Oligocene unconformity and the condensed pelagic facies. C. Latest Miocene. Initiation of a stable (modern) configuration for North Atlantic circulation; deposition of the pelagic drift facies.

cent Iceland Basin, but also swept southward on a broad front across the shoaler areas of the Rockall Plateau. Site 555 shows a complete late early Eocene to early Miocene hiatus, and at Site 117 on the edge of the
Hatton-Rockall Basin, the unconformity extends to the late Oligocene (Fig. 7B).

As the deep North Atlantic basins widened to allow the establishment of bottom gyres, circulation of a more modern configuration developed. Prior to this, the flow through the nascent Irminger and Iceland basins was probably to the south throughout the water column. As the bottom gyre developed, a reversal in bottom-current direction occurred along the basin's eastern margin. With the decrease in current velocity in the widening basins, pelagic deposition of Unit II became prevalent and gradually stabilized into sediment drifts during the mid-Miocene (Fig. 7C). Under this current regime, terrestrial components are present only in small amounts; the pelagic sediments of Unit II are predominantly carbonate ooze and chalk. Composition of the clay minerals, however, is smectitic, suggesting a source in the basaltic terrane of the Iceland-Faeroes region to the north. Although few Miocene to Recent sediment sections in the North Atlantic are without hiatuses, and seismic reflectors are locally prominent within these sections, pelagic deposition had by mid-Miocene become the dominant mode of sedimentation and remained so until the onset of sedimentation under glacial conditions. Attenuation and stabilization of abyssal circulation thus allowed the pelagic facies of Unit II to accumulate under a modern North Atlantic configuration.

In the North Atlantic, the sediment section is capped by the glacial facies which is distinguished by a striking cyclicity of lithofacies. Interglacial sediments are distinguished by oxygen isotope, faunal, and lithofacies analysis (Zimmerman, this volume) and are similar to the subjacent pelagic sediments of Unit II. A similar circulation model, therefore, is proposed for the Mio-Pliocene, interglacial, and the modern North Atlantic. Smectite and mixed-layer clays, which dominate the clay assemblage of these pelagic carbonates, are indicative of subareal or submarine weathering of volcanic terranes; the Iceland/Faeroes region, under this circulation system, being the most immediate source. As described by McCave et al. (1980), the system of abyssal circulation for the Iceland Basin suggests that the transport agent for the fine sediment component is ISOW which, spilling eastward from Gardar Drift, joins with the northeastward-flowing boundary current on Hatton Drift (Fig. 1). However, the similarity of clay-mineral assemblages at shallow Site 555 on the Rockall Plateau and the deeper sites on Hatton Drift suggests that this component is not limited to transport by a specific current, but is dispersed throughout the water column in a pelagic mode.

Sediments deposited under the glacial regime contain little pelagic carbonate and are distinguished by the dominant terrestrial components of clay and ice-rafted coarser sediment. The clay assemblage reflects a terrigenous origin, containing a large abundance of illite (approximately $30 \%$ ) and significant amounts of chlorite and kaolinite. Examination of the X-ray diffractograms reveals a significant quartz-silt component (low TCI/ quartz ratio), emphasizing the importance of the icerafted component under glacial conditions. In general, however, increased erosion of continental areas, ice raft- 
ing, exposure of continental shelves, and a decrease in carbonate productivity under the ice cover of a glacial stage leads to the increase in the terrestrial component in the glacial lithofacies.

\section{ACKNOWLEDGMENTS}

I wish to thank the Deep Sea Drilling Project for the opportunity to participate on Leg 81 and my fellow shipboard scientists for their stimulating collaboration and unflagging good humor. I am grateful to Dr. Floyd McCoy (LDGO), Dr. Hervé Chamley (Lille University), and Andrew Morton (IGS) for their thoughtful and thorough reviews of the manuscript. I am also grateful to Union College for making available the facilities of the Cooledge X-ray Laboratory. This research was supported in part by the National Science Foundation, Grant OCE 82-07164.

\section{REFERENCES}

Berggren, W. A., and Hollister, C. D., 1974. Paleogeography, paleobiogeography and the history of circulation of the Atlantic Ocean. In Hay, W. E. (Ed.), Studies in Paleo-oceanography. Soc. Econ. Paleontol. Mineral., Spec. Publ, 20:126-186.

Biscaye, P. E., 1964. Distinction between kaolinite and chlorite in recent sediments by X-ray diffraction. Am. Mineral., 49:1281-1289.

, 1965. Mineralogy and sedimentation of recent deep-sea clay in the Atlantic Ocean and adjacent seas and oceans. Geol. Soc. Am. Bull., 76:803-831.

Courtois, C., and Chamley, H., 1978. Terres vares et mineraux argileux dans le Crétacé et le Cénozoique de la marge atlantique orientale. C. R. Hebd. Seances Acad Sci., 286, Série D, 671-674.

Debrabant, P., Chamley, H., Foulon, J., and Maillot, H., 1979. Mineralogy and geochemistry of upper Cretaceous and Cenozoic sediments from north Biscay Bay and Rockall Plateau (eastern North Atlantic), DSDP Leg 48. In Montadert, L., Roberts, D. G. et al., Init. Repts. DSDP, 48: Washington (U.S. Govt. Printing Office), 703-726.

Ellett, D. J., and Martin, J. H. A., 1973. The physical and chemical oceanography of the Rockall Channel. Deep-Sea Res., 20:585-625.

Ellett, D. J., and Roberts, D. G., 1973. The overflow of Norwegian Sea Deep Water across the Wyville-Thomson Ridge. Deep-Sea Res., 20:819-835.

Eslinger, E. V., and Savin, S. M., 1976. Mineralogy and $O^{18} / \mathrm{O}^{16}$ ratios of fine-grained quartz and clay from Site 323. In Hollister, C. D., Craddock, C., et al., Init. Repts. DSDP, 35: Washington (U.S. Govt. Printing Office), 489-496.

Gibbs, R. J., 1968. Clay mineral mounting techniques for X-ray diffraction analysis: a discussion. J. Sediment Petrol., 38:242-244.

Goldstein, S. J., and Anderson, T. F., 1981. Oxygen isotope paleooceanography of the Eocene North Atlantic Ocean. Proc. Geol. Soc. Am., 13:461. (Abstract)

Haq, B. U., 1981. Paleogene paleoceanography: Early Cenozoic oceans revisited. Oceanol. Acta, 71-82.

Harrison, R. K., Knox, R. W. O'B., and Morton, A. C., 1979. Petrography and mineralogy of volcanogenic sediments from DSDP Leg 48, Southwest Rockall Plateau, Sites 403 and 404. In Montadert, L., Roberts, D. G. et al., Init. Repts. DSDP, 48: Washington (U.S. Govt. Printing Office), 771-785.

Hayes, J. B., 1973. Clay petrology of mudstones, Leg 18, Deep Sea Drilling Project. In Kulm, L. D., von Huene, R., et al., Init. Repts. $D S D P, 18$ : Washington (U.S. Govt. Printing Office), 903-914.

Jackson, M. L., 1969. Soil Chemical Analysis - Advanced Course (2nd ed.): Madison (Univ. of Wisconsin), Dept. of Soil Science, publ. by the author.

Jones, E. J. W., Ewing, M., Ewing, J. I., and Eittreim, S. L., 1970. Influences of Norwegian Sea overflow water on sedimentation in the northern North Atlantic and Labrador Sea. J. Geophys. Res., $75: 1655-1680$.

Latouche, C., 1979. Clay minerals as indicators of the Cenozoic evolution of the North Atlantic Ocean. In Mortland, M. M. and Farmer, V. C. (Eds.), Intern. Clay Conf. 1978: New York (Elsevier) pp. 271-279.

Latouche, C., and Maillet, N., 1979. X-ray mineralogy studies, Leg 48 - Rockall Region (Sites 403, 404, 405, and 406). In Montadert, L., Roberts, D. G. et al., Init. Repts. DSDP, 48: Washington (U.S. Govt. Printing Office), 665-676.

McCave, I. N., Lonsdale, P. F., Hollister, C. D., and Gardner, W. D., 1980. Sediment transport over the Hatton and Gardar contourite drifts. J. Sediment. Petrol., 50:1049-1062.

McCoy, F. W., and Zimmerman, H. B., in press. Atlas of Paleolithofacies - the Atlantic Ocean. Am. Assoc. Pet. Geol.

McKenna, M. C., 1975. Fossil mammals and early Eocene North Atlantic land continuity. Ann. Mo. Bot. Gard., 62:335-353.

Miller, K. G., and Tucholke, B. E., in press. Development of Cenozoic abyssal circulation south of the Greenland-Scotland Ridge. In Saxov, S. (Ed.), Proc. NATO Adv. Res. Inst. on the Structure and Development of the Greenland-Scotland Ridge: New methods and concepts: New York (Plenum).

Montadert, L., and Roberts, D. G., et al., 1979. Init. Repts. DSDP, 48: Washington (U.S. Govt. Printing Office).

Müller, C., 1976. Tertiary and Quaternary calcareous nannoplankton in the Norwegian-Greenland Sea, DSDP Leg 38. In Talwani, M., Udintsev, G., et al., Init. Repts. DSDP, 38: Washington (U.S. Govt. Printing Office), 823-841.

Odin, G. S., and Matter, A., 1981. De Glauconiarum origine. Sedimentology, 28:611-641.

Reynolds, R. C., Jr., and Hower, J., 1970. The nature of interlayering in mixed-layer illite-montmorillonites. Clays Clay Miner., 18:25-36.

Roberts, D. G., 1975. Marine geology of the Rockall Plateau and Trough. Philos. Trans. R. Soc. London, 278:447-509.

Roberts, D. G., and Montadert, L., 1979. Evolution of passive rifted margins - perspective and retrospective of DSDP Leg 48. In Montadert, L., Roberts, D. G., et al., Init. Repts. DSDP, 48: Washington (U.S. Govt. Printing Office), 1143-1153.

Ruddiman, W. F., 1972. Sediment redistribution on the Reykjanes Ridge: seismic evidence. Geol. Soc. Am. Bull., 83:2039-2062.

Talwani, M., and Udintsev, G., 1976. Tectonic synthesis. In Talwani, M., Udintsev, G., et al., Init. Repts. DSDP, 38: Washington (U.S. Govt. Printing Office), 1213-1242.

Thiede, J., 1980. Palaeo-oceanography, margin stratigraphy and palaeophysiography of the Tertiary North Atlantic and NorwegianGreenland Seas. Philos. Trans. R. Soc. London, A294:177-185.

Vergnaud Grazzini, C., Pierre, C., and Létolle, R., 1978. Paleoenvironment of the Northeast Atlantic during the Cenozoic: oxygen and carbon isotope analyses at DSDP Sites 398, 400 and 401. Oceanol. Acta, 1:381-390.

Vogt, P. R., 1972. The Faeroe-Iceland-Greenland aseismic ridge and the western boundary undercurrent. Nature (London), 239:79-81.

Worthington, L. V., 1970. The Norwegian Sea as a mediterranean basin. Deep-Sea Res., 17:77-84.

Zimmerman, H. B., 1982a. Lithologic stratigraphy and clay mineralogy of the western Caribbean and eastern equatorial Pacific, Leg 68, Deep Sea Drilling Project. In Prell, W. L., Gardner, J. V., et al., Init. Repts. DSDP, 68: Washington (U.S. Govt. Printing Office), 383-395.

1982b. Fine-grained sediment distribution in the late Pleistocene/Holocene North Atlantic. Bull. Inst. Géol. Bassin Aquitaine, Bordeaux, 31:337-357.

Date of Acceptance: October 15, 1983 